RAD Conference Proceedings, vol. 2, pp. 19-24, 2017

www.rad-proceedings.org

20.0001 tht

\title{
INFLUENCE OF VARIOUS FACTORS ON THE LACTOCOCCUS LACTIS CELLS
}

\author{
L.G.Stoyanova ${ }^{1^{*}}$, L.P.Blinkova ${ }^{2}$, Yu.D.Pakhomov ${ }^{2}$, S. Dbar ${ }^{1}$
}

${ }^{1}$ M.V. Lomonosov Moscow State University, Department of Microbiology, Russia 2I.I. Mechnikov Research Institute of Vaccines and Sera, Moscow, Russia

\begin{abstract}
Bacteriocin-producing strains of Lactococcus lactis subsp. lactis of different origin were used in our experiments. UV-Irradiation of cells of bacteriocin-synthesizing lactoococci of different origin in a dose of 7.6-760o $\mathrm{erg} / \mathrm{mm}^{2}$ was followed by their selective growth in an MRS medium, and their selection after UV-ray treatment. Some strains of lactococci had double UV treatment. The novel most active bacteriocin-producing strains were restored after lyophilization and storage. An exposure of 10 minutes should be considered an effective dose of treatment for wide strain 229. As a result, No.12 with an antibiotic activity of $3850 \mathrm{IU} / \mathrm{mL}$ was selected, which is 54 $\%$ higher than the initial one. The study of the physiological and biochemical properties of the variants, selected after $U V$-ray treatment, showed that they somewhat changed the rate of their growth and the accumulation of bacteriocin. The relative activity in the production of bacteriocin was calculated as the ratio of activity values and the number of produced cells. The inactivated homologous strain biomass and amino acids were applied as the factors of resuscitation. The control culture liquid was without supplements. VBNC cells of opportunistic strains formed within the first days of incubation. After 1 year of incubation, the VBNC values of Klebsiella pneumoniae 1954, Alcaligenes faecalis 415, Enterobacter aerogenes 418, Proteus vulgaris HX19222, Salmonella typhimurium were statistically equal (97.1-99.9\%). After 1 day of stress, the strains of L. lactis did not form colonies up to $60-80 \%$, after 5 days up to 82.1-99.6\%, and after 1 year-99.9\%. Unwashed from the culture fluid, the inoculated cells proliferated and passed to the VBNC faster. With that inoculation, the nisin productive activity of cells was lower 10-78 times, depending on the strain of L. lactis. The study of resuscitation factors has shown that the supplement of homologous inactivated biomass of L. lactis $(0.1 \%, 0.5 \%, 1 \%$ ) was effective with $1 \%$ (a magnification of 2.65 at $p<0.05$ ) and $0.5 \%$ (magnification of 3.75 at $p<0.05$ ) only for the MSU strain. Strain F-116 was marked by a 4-fold increase in the ability for cultivation after the addition of 7 aminoacids: (glutamine, methionine, leucine, isoleucine, histidine, arginine, valine). After 1 year, the quantitative level of VBNC cells, which formed in the first days of incubation, was the same for opportunistic and probiotic cultures (97.1\%-99.9\%). All studied resuscitation factors were individually effective for bacterial strains.
\end{abstract}

Key words: Lactococcus lactis subsp. lactis, bacteriocin, nisin, opportunistic strains, factors, lactococci, resuscitation, UV-light, VBNC cells

DOI: $10.21175 / \operatorname{RadProc} .2017 .05$

\section{INTRODUCTION}

The most effective among the various factors whose impact can lead to a change in the properties of bacteria or a whole cell population are gamma or UVirradiation [1]-[4]. It is known that sensitivity to UV is not the same for different bacterial species and strains. The radiation is enhanced by the formation of active free radicals, which are the cause of the non-genetic effects of radiation on organisms and capable to induce biochemical processes in cells. In the initial stage of the development of a culture, the enzymes of the intracellular fund are activated by "SOS" proteins, which protect the cell from unfavorable factors. It should be noted that natural peptides synthesized by microorganisms possess antimutagenic properties, which is important for creating probiotic preparations [5]. Genus Lactococcus has the "GRAS" status (absolutely harmless for human health and animals) according to the European Commission [6]. The physiological property of these bacteria is the synthesis of antimicrobial peptides - bacteriocins - which are the main component of probiotic preparations. Generally, probiotics may be defined as a safe and "natural" approach that helps to curb the population of bacteria that cause microbial infections. Lactococcci and their bacteriocins are widely used in various food fermentations and have a long history. Nisin is a unique, nontoxic antibiotic and it is the best studied compound in the bacteriocin group [7]. It is the only antibiotic substance given the status "GRAS", which is allowed for application as a food preservative under the code E234. Nisin is a low-molecular mass protein so it is easy to separate it into amino acids during digestion and it does not influence the microbiota of the gastrointestinal tract [8]. One of the very important properties of nisin is the activity against Gram-positive bacteria and bacterial spores of clostridia and bacilli, other non-spore forming bacteria, as well as many species of pathogenic Streptococcus, Staphylococcus, and Listeria, but it is not effective against Gram-

* stoyanovamsu@mail.ru 
negative enterobacteria and fungi [7]. The receipt of highly active producers of bacteriocins of a wide spectrum of action is an actual task. Various methods are used for breeding. Due to the effect on cells, such factors as radiation and other stresses (starvation, temperature, oxygenization, osmotic pressure, lyophilization etc.) appear viable, but the properties of uncultivated cells (VBNC) were insufficiently studied [1]-[4], [9]-[14]. VBNC cells can be resuscitated using serum, amino acids, vitamin $\mathrm{K}$, blood-substitute etc. [11], [15]-[16].After exposure, the bacteria may return to their proliferation and metabolism.

There is evidence that VBNC bacteria appear under the influence of gamma-radiation at a dose higher than $0.5^{-2} \mathrm{kGy}$ and UV-radiation at a dose of about 300 $\mathrm{mJ} / \mathrm{sm}^{2}[1]-[4]$. The cells in the VBNC state are small and do not form colonies (CFU/ml). Metabolic processes, including the synthesis of bacteriocins, reduce the speed. The presence of VBNC bacteria in food, water, soil, organisms etc. may significantly reduce the total number of registrable pathogens; therefore, there is a danger of infection. Thus, it is necessary to study the condition of the formation of the VBNC state and the factors of cell resuscitation.

The aim of our research was the induction of biochemical processes of lactococci under the influence of UV-radiation, and the studying of the formation of the VBNC state under starvation influence and the cell reversion into normal state.

\section{MATERIALS AND METHODS}

In our experiments we used 3 probiotic strains of lactococci: one wild strain 229 with a bacteriocin activity of $2500 \mathrm{IU} / \mathrm{ml}$ (as nisin) was isolated from the cow milk from the Moscow Region; fusant strain F-116 (4200 IU/ml) was obtained after a protoplast fusion of two related strains with low nisin-synthesizing activities; and a classic nisin producing strain MSU with the activity of $2000 \mathrm{IU} / \mathrm{ml}$ [17], [18]. All strains were identified as L.lactis ssp. lactis (GenBank accession no. DQ 255954, EF100777, DQ255952, respectively). The induction by ultraviolet light (UVL) was studied for the variability of the wild strain 229 on the synthesis of nisin. The source of UV-irradiation was an installation of two parallel-mounted lamps BUV-15 $(30 \mathrm{~W})$, the main emission of which falls on the area of $253.7 \mathrm{~nm}$. Doses of UV-irradiation were measured using a UVD-4 dosimeter. The biomass was determined nephelometrically at a wavelength of 600 $\mathrm{nm}$. In this work, the effect of UVL on intact cells of the actively growing culture of the logarithmic growth stage, most sensitive to the action of UVL, was studied. Prior to irradiation, the cells were separated from the culture liquid by centrifugation at $1380 \mathrm{~g}$ for $20 \mathrm{~min}$, washed twice with stabilizing ammonium citrate buffer with disodium ethylenediaminetetraacetate dehydrate (EDTA-Na $\mathrm{N}_{2}$ )with a pH of 6.4. The bacterial suspension was resuspended in buffer in an amount of $5 \mathrm{ml}$, and irradiated in an open Petri dish for 1, 5, 10, 15, 20 minutes, which corresponded to 7.6-76 thousand erg / $\mathrm{mm}^{2}$. To determine the survival rate, tenfold dilutions of control and experimental samples exposed to irradiation were carried out. Irradiated cells from a series of dilutions in the buffer were grown in a rich full-fledged MRS medium with the following composition (g / l): casein hydrolyzate - 10, glucose $20, \mathrm{~K}_{2} \mathrm{HPO}_{4} \mathrm{xH}_{2} \mathrm{O}-2$, yeast extract $-2, \mathrm{Na}-5$ acetate, $\mathrm{MgSO}_{4} \mathrm{xH}_{2} \mathrm{O}-0.2, \mathrm{MnSO}_{4} \mathrm{xH}_{2} \mathrm{O}-0.05$ and an addition of $25 \mathrm{ml}$ of $0.7 \%$ cysteine solution, and $1 \mathrm{ml}$ of tween-80 suspensions of bacteria with subsequent sowing on dense media. The grown colonies were chopped by a replicator into agar medium MRS supplemented with $1.5 \%$ agar and $200 \mu \mathrm{g} / \mathrm{ml}$ nisin in order to accelerate the selection process according to the specified characteristic. They were incubated for two days in a thermostat at $28^{\circ} \mathrm{C}$. After each exposure, the samples were centrifuged and washed with buffer to stop the mutagen. Then a direct count of the colonies was carried out. The bacteriocin product was provided by a diffusion method on the agar plate with Bacillus coagulans 429 as an indicator culture [14]. The grown colonies were interchanged by the replicator on the selective medium of MRS, and then on the agar MRS and MRS medium with $B$. coagulans. The influence of nisin as a selective component of the medium on the segregation of clones and their antibiotic activity was studied. The spontaneous and UV-induced variability of the strains was determined on the basis of antimicrobial activities. Colonies with the greatest inhibitory zones were selected. Some lactococci had double UV treatment. Active variants of lactococci were lyophilized on a "Krist" system of the brand Betta A (Germany) under vacuum at a temperature of $-30^{\circ} \mathrm{C}$ to a residual moisture content of $2.5-4.0 \%$ and stored. Changes in their antibiotic and enzymatic activity were studied afterwards. Sensitivity to antibiotics was determined by the discodiffusion method [18]. The relative activity in the production of bacteriocin was calculated as the ratio of activity values and the number of produced bacteriocin cells. Quantitative determination of the antimicrobial activity was performed by measuring the zones of growth suppression with subsequent calculation involving a calibration plot for standard nisin solutions. Solutions of the preparations served as the standards: "Nisaplin (activity $1 \mathrm{mln}$. IU/g, “Aplin \& Barrett”, Ltd.,UK). The obtained active variants of lactococci strains were also compared according to their cultural, physiological, and biochemical properties with the classical nisinproducing strain MSU and the recombinant strain F116. The spectrum of inhibitory effects of the strains was studied by culturing strains under steady-state conditions in the medium of the above composition. The microorganisms used in these experiments were from the CM-MSU (Table 2).

The lactococci and the opportunistic strains Proteus vulgaris HX19222, Klebsiella pneumoniae 1954, Enterobacter aerogenes GISK 418, Alcaligenes faecalis 415, and Salmonella Typhimurium 79 were used concerning the study of the VBNC state.

We used trophic starvation as a stress factor. For this purpose, opportunistic and lactococci strains were inoculated in special media. The monitoring of viability and nonculturability was performed in a period of up to 1 year. The total number of live and dead cells was counted under light and luminescent microscopes after staining with a Live/Dead ${ }^{\circledR}$ double staining kit. The colony numbers were determined $(\mathrm{CFU} / \mathrm{ml})$ on the plates with a nutrient medium. The value for the VBNC bacteria was determined by comparing the total 
numbers of viable and CFU cells. Statistical data reliability was at the level of $\leq 0.05$. The temperature inactivated the biomass of homologous strains and the 7 amino acids (glutamine, methionine, leucine, histidine, arginine, valine) were applied as a factor of resuscitation. The control culture liquid was without supplements. There is evidence of an effective influence of various factors for getting substrains with more bacteriocin activity in the VBNC state and the resuscitation of the cells.

\section{RESULTS}

The results of studying the spontaneous variability of the natural strain L. lactis subsp. lactis 229 on the basis of nisin formation on an agar MRS medium showed that the culture was not homogeneous. The activity spread fluctuated from 500 to $2700 \mathrm{IU} / \mathrm{ml}$, where $71 \%$ of the 52 clones selected for the study had an activity level in the range $2300-2700 \mathrm{IU} / \mathrm{ml}$, while $29 \%$ had an activity below the level of the parent. UV irradiation for $1 \mathrm{~min}$ without a significant effect on the survival of lactococci still somewhat changed the distribution of clones according to their antibiotic activity: $11.8 \%$ of the 52 clones selected for the study lost activity, while $34.5 \%$ had a level of activity of the parent strain 229. However, clones with increased antibiotic activity were not detected. Only $11.1 \%$ “+” variants were isolated with treatment of the bacterial suspension for 10 minutes, with an activity level higher than the initial level (Table 1).

Table 1. Effect of ultraviolet irradiation on the nisin-synthesizing activity of Lactococcus lactis subsp. lactis strain 229

\begin{tabular}{|c|c|c|c|c|}
\hline \multirow{2}{*}{$\begin{array}{c}\text { Time of irradiation, } \\
\text { min }\end{array}$} & \multicolumn{3}{|c|}{ Distribution of options for nisin-synthesizing activity, \% } \\
\cline { 2 - 5 } & Lost activity & $\begin{array}{c}\text { Below control } \\
\text { level }\end{array}$ & Control & " variants \\
\hline 0 & 0 & $24.0 \pm 1.1$ & $66.0 \pm 2.2$ & 0 \\
\hline 1 & $11.8 \pm 0.7$ & $34.5 \pm 1.2$ & $54.7 \pm 1.8$ & 0 \\
\hline 5 & $29.3 \pm 0.2$ & $36.3 \pm 1.5$ & $34.2 \pm 1.3$ & $11.1 \pm 0.3$ \\
\hline 10 & $53.1 \pm 2.1$ & $12.0 \pm 0.5$ & $23.8 \pm 0.7$ & 0 \\
\hline
\end{tabular}

In a low-lying environment, UV exposure to the strain for 1 min caused a different distribution of the clones $-32.5 \%$ lost activity, 56\% had activity from 2500 to $2900 \mathrm{IU} / \mathrm{ml}$, i.e., induction of nisin formation was not observed. During treatment for 10 minutes, $14.2 \%$ of the colonies already had antibiotic activity in the range from 3000 to $3350 \mathrm{IU} / \mathrm{ml}$. The distribution of lactococci by their nisin-synthesizing activity was as follows: $54 \%$ of surviving cells lost activity, $21.8 \%$ had lower activity, and $24.2 \%$ of cells had activity at a baseline level; therefore, an effective dose of treatment for this strain should be a dose of $76,000 \mathrm{erg} / \mathrm{mm}^{2}$ (corresponds to an exposure of $10 \mathrm{~min}$ ). As a result, strain No. 6 with antibiotic activity 25\% higher than the original one was selected. Its colonies on the agar medium were larger, from 1.0 to $2.1 \mathrm{~mm}$ in diameter, and less transparent, possibly due to thickening of the peptidoglycan layer of the cell wall. There is also a dissociation of the culture under the UV-ray treatment, which is manifested in the change of the strain according to the morphological and biochemical features, as a consequence of which inactive populations accumulate inactive variants of antibiotic formation or induction of the desired trait. In the cultivation of variant No. 6 in the MRS medium, biomass and nisin synthesis reached their maximum by 9 hours, i.e. two hours ahead of the growth rate of the original strain 229. However, strain No. 6 lost the ability to utilize ribose, worse than the original fermented disaccharide maltose and lactose, but more actively fermented sucrose, and hydrolyzed dextrin. This variant became less sensitive to the antibiotic that inhibits the synthesis of the cell wall of Gram-positive bacteria - penicillins (benzylpenicillin, carbenicillin, ampicillin, methicillin, oxacillin) - but not to cephalosporins (cephalothin and cephalexin). It acquired resistance to broad-spectrum antibiotics inhibiting RNA synthesis aminoglycosides (sisomycin and kanamycin), and retained resistance to neomycin.
Colonies that gave high activity were re-treated with UVL in the optimal dose (10 min exposure). At that, the survival rate of variant No. 6 was $0.3 \%$, and the number of "+" variants was $17 \%$. The following segregation of clones for nisinogenesis was observed: $22 \%$ had antibiotic activity from 1500-2000 IU / ml, $0 \%$ from $3000-3500 \mathrm{IU} / \mathrm{ml}$, and $17 \%$ of positive bacterial clones ("+" variants) from 3500-3700 IU / $\mathrm{ml}$, i.e., an increase in activity by $48 \%$. It should be noted that in the population there were no clones sensitive to the nisin. Perhaps, along with the induction of nisinogenesis, the strain acquired resistance to nisin.

As a result of double, stepwise treatment of "+" strains, No. 12 variants were obtained with a nisinsynthesizing activity of $3850 \mathrm{IU} / \mathrm{ml}$. A study of the dynamics of growth and development of variant No. 12 showed that double UV treatment extended the exponential phase of growth to 15 hours, and by the same time, the level of accumulation of nisin reached its maximum of $3850 \mathrm{IU} / \mathrm{ml}$. With regard to fermentation of carbohydrates, this strain showed similarity to the initial strain regarding the consumption of pentoses, but became more resistant to a number of antibiotics: lincomycin, doxycycline, levomycetin, oleandomycin, streptomycin and tetracycline.

The results of our study of the spectra of antimicrobial action of culture liquids of the studied strains are summarized in Table 2. The wild strain 229 as strain MSU suppressed the growth of Gram-positive bacilli and cocci, including Bacillus coagulans, Listeria monocytogenes, and Staphylococcus aureus only in a manner similar to that of nisin. But nisin is not effective against enterobacteria. The study of the antimicrobial spectrum of action showed that fusant strain F-116 also suppressed the growth of Grampositive bacteria as well as some Gram-negative cultures, including opportunistics and fungi, which is a 
rare biological property for the natural strains of this species.

The fusant strain F-116 has a broad spectrum of antimicrobial action. It has been revealed, that the strain F-116 produced an antibiotic complex which differed from nisin [19]. UVL "+" variants No. 6 and 12 suppressed the growth of Gram-positive bacteria, but No. 12 had antifungal activity.

Obtained after treatment with UVL “+” variants after lyophilization, after 1-1.5 months, storage strains were restored and changes in their antibiotic and enzymatic activity in a number of passages were studied. It was established that, after 10 passages, strain No. 6 was noticed to resemble the original wild type both in terms of the level of antibiotic and enzymatic activity. Variant No. 12, obtained by stepwise, double UV light treatment, retained the stability of the changed properties, including the spectrum of antimicrobial activity (Table 2). The main component of the cell, responsible for sensitivity to ultraviolet rays, is its DNA. In response to DNA damage in the cell, the processes of restoring the original DNA structure and a mutagenesis mechanism are activated, ensuring the viability of cells with potentially lethal genome damage [5].

Table 2. Antimicrobial action of strains of Lactococcus lactis ssp. lactis in comparison with "Nisaplin"

\begin{tabular}{|c|c|c|c|c|c|c|}
\hline \multirow{3}{*}{ Test-microorganisms } & \multicolumn{6}{|c|}{ Strains } \\
\hline & 229 & 12 & 6 & $\mathrm{~F}-116$ & MSU & $\begin{array}{c}\text { Nisaplin } \\
3000 \mathrm{IU} / \mathrm{ml}\end{array}$ \\
\hline & \multicolumn{6}{|c|}{ Diameter of inhibition zone, $\mathrm{mm}$} \\
\hline Bacillus coagulans & 17.0 & 23.0 & 20.0 & 26.0 & 15.0 & 17.0 \\
\hline Bacillus subtilis & 17.0 & 21.0 & 19.0 & 24.0 & 16.0 & 18.0 \\
\hline Micrococcus luteus & 19.0 & 21.0 & 9.0 & 27.0 & 18.0 & 21.0 \\
\hline Bacillus cereus & 16.0 & 18.5 & 16.0 & 18.0 & 16.0 & 18.0 \\
\hline Staphylococcus aureus & 20.0 & 21.5 & 19.0 & 19.0 & 19.0 & 25.0 \\
\hline Listeria monocytogenes & 15.0 & 17.0 & 14.0 & 16.0 & 12.0 & 15.0 \\
\hline Salmonella Typhimurium & o & o & o & 17.0 & o & $\mathrm{O}$ \\
\hline Escherichia coli & o & 10.0 & o & 18.0 & o & o \\
\hline Proteus vulgaris & o & 9.0 & $\mathrm{O}$ & 16.0 & o & $\mathrm{O}$ \\
\hline Klebsiella pneumoniae & o & o & $\mathrm{O}$ & 12.0 & o & $\mathrm{O}$ \\
\hline Enterobacter aerogenes & o & o & o & 14.0 & o & $\mathrm{o}$ \\
\hline Alcaligenes faecalis & o & o & o & 16.0 & o & o \\
\hline Aspergillus niger & o & 10 & $\mathrm{O}$ & 17.0 & o & $\mathrm{O}$ \\
\hline Rhodotorula aurantiaca & o & 10.0 & o & 14.0 & o & o \\
\hline Candida guellermondii & o & 9.0 & o & 16.0 & $\mathrm{O}$ & o \\
\hline
\end{tabular}

The VBNC cells of the opportunistic cultures Klebsiella pneumoniae 1954, Alcaligenes faecalis 415, Enterobacter aeruginosa 418, Proteus vulgaris HX19222, and Salmonella Typhimurium 79 were formed within the first days of incubation. The VBNC value of these strains moved to statistically equal (9799\%). The study of the date of the transition of opportunistic bacteria in the VBNC state [Table 3] showed that after 1 year of incubation, $99.99 \%$ of $P$. vulgaris HX19222 did not form colonies, while with $K$. pneumoniae $1954-97.1 \%$ of the cells, i.e., bacterial cells, moved into the VBNC state. The values observed for E. aerogenes and S. Typhimurium GISK418 79 (about 99.1\%) and A. faecalis 415 (99.33\%) were close to VBNC values of aforementioned cultures. The most viable cultures were $E$. aerogenes and $P$. vulgaris GISK418 HX19222 (99.6\% and 99.49\% were alive, respectively). At the same time, $A$. faecalis 415 and $K$. pneumoniae 1954 had $68.6 \%$ and $66.4 \%$ of living cells, respectively.

Table 3. Viability and nonculturability of opportunistic bacteria

\begin{tabular}{|c|c|c|c|c|c|c|}
\hline \multirow[b]{2}{*}{ Bacteria } & \multirow{2}{*}{$\begin{array}{c}\text { Maximum value } \\
\mathrm{CFU} / \mathrm{ml} \\
\text { (incubation } \\
\text { period) }\end{array}$} & \multicolumn{5}{|c|}{ Values in a year incubation } \\
\hline & & $\mathrm{CFU} / \mathrm{ml}$ & $\begin{array}{c}\text { total cell } \\
\text { number per ml }\end{array}$ & $\%$ live cell & $\begin{array}{l}\% \text { cells } \\
\text { forming } \\
\text { colonies }\end{array}$ & $\begin{array}{c}\% \text { VBNC } \\
\text { cells }\end{array}$ \\
\hline $\begin{array}{c}\text { Proteus vulgaris } \\
\text { HX19222 }\end{array}$ & $\begin{array}{c}4.77 \pm 0.52 \times 10^{8} \\
(2 \text { days })\end{array}$ & $2.10 \pm 0.23 \times 10^{3}$ & $5.80 \pm 0.64 \times 10^{7}$ & 94.4 & 0.0036 & 99.99 \\
\hline $\begin{array}{c}\text { Klebsiella } \\
\text { pneumoniae } 1954\end{array}$ & $\begin{array}{c}3.89 \pm 0.26 \times 10^{8} \\
(2 \text { days })\end{array}$ & $5.42 \pm 0.6 \times 10^{6}$ & $2.76 \pm 0.3 \times 10^{8}$ & 66.4 & 2.9 & 97.1 \\
\hline $\begin{array}{c}\text { Enterobacter } \\
\text { aerogenes GISK } 418\end{array}$ & $\begin{array}{c}4.9 \pm 0.54 \times 10^{8} \\
(7 \text { days })\end{array}$ & $2.15 \pm 0.24 \times 10^{6}$ & $2.5^{8} \pm 0.25 \times 10^{8}$ & 99.6 & 0.84 & 99.16 \\
\hline $\begin{array}{c}\text { Alcaligenes faecalis } \\
415\end{array}$ & $\begin{array}{c}7.1 \pm 0.78 \times 10^{7} \\
(1 \text { month })\end{array}$ & $5.09 \pm 0.56 \times 10^{5}$ & $1.10 \pm 0.12 \times 10^{8}$ & 68.6 & 0.67 & 99.33 \\
\hline
\end{tabular}


As for the VBNC L. lactis ssp. lactis (strains MSU and F-116), which was formed from two different types of inoculum, washed (W) and unwashed (UW), after 24 hours of incubation, $60-80 \%$ did not form colonies on the synthetic medium. After 5-7 days of incubation, there was about $82-99.6 \%$ of them and, in a year, $99.9 \%$ of the cells did not form colonies depending on the conditions of the experiment. The lactococci population, which was obtained with unwashed inoculum, entered the state of VBNC faster and in a greater amount, but the total number of cells was opposite (Table 4). Perhaps, these cells were significantly more sensitive to trophic stress.

Table 4. Dynamics of bacteriocin-producing activity in Lactococcus lactis ssp. lactis MSU and F-116 strains populations during carbohydrate starvation

\begin{tabular}{|c|c|c|c|c|c|c|c|}
\hline \multirow[t]{2}{*}{$\begin{array}{l}\text { Time of } \\
\text { incubation }\end{array}$} & \multirow[t]{2}{*}{$\begin{array}{c}\text { Type of } \\
\text { inoculum }\end{array}$} & \multicolumn{2}{|c|}{ Total number of cells per ml } & \multicolumn{2}{|c|}{$\begin{array}{c}\text { Relative bacteriocin } \\
\text { productivity IU } / 10^{9} \\
\text { cells/ml }\end{array}$} & \multicolumn{2}{|c|}{$\begin{array}{l}\text { Multiplicity of differences in } \\
\text { relative bacteriocin activity } \\
\text { between UW and } W \text { variants }\end{array}$} \\
\hline & & MSU & F-116 & MSU & F-116 & MSU & F-116 \\
\hline \multirow{2}{*}{1 day } & UW & $(1.5 \pm 0.2) \times 10^{9}$ & $(1.5 \pm 0.2) \times 10^{9}$ & 2069 & 1633 & \multirow{2}{*}{25.1} & \multirow{2}{*}{41.8} \\
\hline & $\mathrm{W}$ & $(4.7 \pm 0.5) \times 10^{7}$ & $(4.3 \pm 0.5) \times 10^{7}$ & 51906 & 68287 & & \\
\hline \multirow{2}{*}{2 days } & UW & $(1.6 \pm 0.2) \times 10^{9}$ & $(1.4 \pm 0.2) \times 10^{9}$ & 2083 & 1713 & \multirow{2}{*}{$35 \cdot 3$} & \multirow{2}{*}{$55 \cdot 4$} \\
\hline & $\mathrm{W}$ & $(3.4 \pm 0.4) \times 10^{7}$ & $(3.2 \pm 0.4) \times 10^{7}$ & 73529 & 94936 & & \\
\hline \multirow{2}{*}{7 days } & UW & $(1.8 \pm 0.2) \times 10^{9}$ & $(1.2 \pm 0.1) \times 10^{9}$ & 1525 & 2379 & \multirow{2}{*}{41.7} & \multirow{2}{*}{26.7} \\
\hline & $\mathrm{W}$ & $(4.4 \pm 0.5) \times 10^{7}$ & $(4.7 \pm 0.5) \times 10^{7}$ & 63636 & 63559 & & \\
\hline \multirow{2}{*}{10 days } & UW & $(2.1 \pm 0.2) \times 10^{9}$ & $(1.3 \pm 0.1) \times 10^{9}$ & 1322 & 1870 & \multirow{2}{*}{35.1} & \multirow{2}{*}{36.8} \\
\hline & W & $(5.3 \pm 1.6) \times 10^{7}$ & $(3.6 \pm 0.4) \times 10^{7}$ & 46402 & 68820 & & \\
\hline \multirow{2}{*}{1 year } & UW & $(8.8 \pm 1) \times 10^{8}$ & $(1.1 \pm 0.1) \times 10^{9}$ & 3111 & 2641 & \multirow{2}{*}{0.44} & \multirow{2}{*}{18.9} \\
\hline & $\mathrm{W}$ & $(2.0 \pm 0.2) \times 10^{7}$ & $(4.9 \pm 0.5) \times 10^{7}$ & 1375 & 49796 & & \\
\hline
\end{tabular}

Table 4 shows that the relative activity of bacteriocin-producing VBNC cells with W-inoculum was always greater than with UW-inoculum for the MSU and F-116 strains. Maximum differences were 41.7 (MSU) and 54.4 (F-116). In separate experiments the relative activity differed 78 times.

\section{CONCLUSION}

Thus, under the action of UV-rays and other stress factors, including trophic starvation, the mechanism of change of the cells properties was launched; they were allowed to obtain the $L$. lactis substrain with a higher bacterial productivity or created conditions for the emergence of VBNC bacteria. Furthermore, using a homologous biomass of lactococci and aminoacids, VBNC cells were resuscitated to a normal state. The studied processes are of practical importance. For example, the new substrains of lactococci are more promising for the production of bacteriocin. Bacteriocins are used for treatment or to ensure the safety of food products. The experimental detection of reversion shows the danger of a lack of appropriate monitoring of the presence of dormant microbes. It is necessary to discover the VBNC bacteria in clinical material, food, environmental objects, etc.

The study of resuscitation factors showed that the supplement of a homologous inactivated biomass of $L$. lactis $(0.1 \%, 0.5 \%, 1 \%)$ was effective with $1 \%$ (a magnification of 2.65 at $\mathrm{p}<0.05)$ and $0.5 \%$ (magnification of 3.75 at $\mathrm{p}<0.05$ ) only for the MSU strain. For the fusant strain, L. lactis F-116 showed a 4 -fold increase in the ability of cultivation after the addition of a 7-aminoacid mixture.

\section{REFERENCES}

1. B. J. Pitonzo, P.S. Amy, M. Pudin, "Effect of gamma radiation on native endolithic microorganisms from a radioactive waste deposit site," Radiation Research, vol. 152, no. 1, pp. $64-70$, Jul. 1999.

DOI: $10.2307 / 3580050$ PMid: 10381842

2. S. Saroj, R. Shashidhar, J. Bandekar, "Gamma radiation used as hygienization technique for foods does not induce viable but non-culturable state (VBNC) in Salmonella enterica ssp. Enterica," Curr. Microbiol., vol. 59, no. 4, pp. 420 - 424, Oct. 2009.

DOI: $10.1007 / \mathrm{s}$ 00284-009-9454-3 PMid: 19641961

3. M. Parikka, M. M. Hammaren, S. K. Harjula, J.A. Haltpenny et al., "Mycobacterium marinum causes a latent infection that can be reactivated by gamma irradiation in adult zebratish," Plos pathogens, vol. 8, no. 9, pp. 1 - 14, Sep. 2012.

DOI: 10.1371/journal.ppat.1002944

PMid: 23028333

PMCid: PMC3459992

4. S. Zhang, C. Ye, H. Lin, L. V. Zu, X. Yu, "UV disinfection induces a VBNC state in Escherichia and Pseudomonas aeruginosa," Environmental science and technology, vol. 49, no. 3, Jan. 2015. DOI: $10.1021 /$ es505211e

5. L. I. Vorob'eva, N. G. Loiko et al., "Effect of the Reactivating Factor of Luteococcus japonicus subsp. casei on the Expression of SOS Response Genes," Microbiology, vol. 82, no. 2., pp. 126 - 132, Mar. 2013. DOI: 10.1134/Soo26261713020094

6. European Parliament. (Jan. 27, 1997). No 258/97 Concerning novel foods and novel food ingredients. Retrieved from:

http://eur-lex.europa.eu/legalcontent/EN/TXT/PDF/?uri=CELEX:31997R0258\&fro $\underline{m}=\mathrm{EN}$ Retrieved on: Jan. 18, 2017

7. N. Bernhom, T. R. Licht et al., "Effects of Lactococcus lactis on Composition of intestinal Microbiota: Role of 
Nisin," Applied Environmental Microbiology, vol. 72, no. 1, pp. 1239 - 244, Jan. 2006.

DOI: 10.1128/AEM.72.1.239-244.2006

PMid: 16391049

PMCid: PMC1352298

8. L. G. Stoyanova, E. A. Ustiugova, A. I. Netrusov, "Antibacterial metabolites of lactic acid bacteria: their diversity and properties," Appl. Biochem. Microbiol., vol. 48, no. 3, pp. 259 - 275, May 2012.

DOI: $10.1134 /$ SoO03683812030143 PMid: 22834296

9. V. C. Trainor, R. K. Udy, P. J. Bremer, G. M. Cook, "Survival of Streptococcus pyogenes under stress and starvation," FEMS Microbiol. Lett., vol. 176, no. 2, pp. $421-428$, Jul. 1999.

DOI: $10.1111 / \mathrm{j} .1574-6968.1999 . t b 13692 . x$ PMid: 10427725

10. V. Besnard et al., "Capelier Enviromental and physico-chemical factors induce VBNC state in Listeria monocytogenes," Veterinary Research, vol. 33, no. 4, pp. $359-370$, Jul-Aug. 2002.

DOI: $10.1051 /$ vetres:2002022 PMid: 12199363

11. J. D. Oliver, F. Hite, D. McDougald, N. L. Andon, J. M. Simpson, "Entry into and resuscitation from the viable but nonculturable state Vibrio vulnificus in entuarine environment," Applied and Environmental Microbiology, vol. 61, no. 7, pp. 2624 - 2630, Jul. 1995. PMid: 7618874 PMCid: PMC167534

12. D. Oliver, "The viable but nonculturable state in bacteria," J. Microbiol., vol. 43, pp. $93-100$, Feb. 2005. PMid: 15765062

13. L. Blinkova, D. M. Martirosyan et al., "Nonculturable bacteria in lyophilized probiotic preparations," The Journal of Functional Foods in Health and Disease, vol. 4, no. 2, pp. 66 - 76, Feb. 2014. Retrieved from: http://ffhdj.com/index.php/ffhd/article/view/29/66 Retrieved on: Dec. 19, 2016
14. M. D. Whitesides, J. D. Oliver, "Resuscitation of Vibrio vulnificus from the viable but nonculturable state," Appl. Environ. Microbiol., vol. 63, no. 3, pp. 10021005, Mar. 1997.

PMid: 16535534 PMCid: PMC1389128

15. L. P. Blinkova, Yu. D. Pakhomov, N. N. Scorlupkina, "Detection and resuscitation of viable but nonculturable bacteria in vaccines and other biomedical preparations," presented at the 2016 Int. Conf. "Toolkits for DNA vaccine design, an update", Moscow, Russia, 2016.

16. B. Ganesan, M. R. Stuart, B. C. Weiner, "Carbohydrate starvation causes a metabolically active but nonculturable state in Lactococcus lactis," Appl. Environ. Microbiol., vol. 73, no. 8, pp. 2498 - 2512, Apr. 2007.

DOI: 10.1128/AEM.01832-06

PMid: 17293521

PMCid: PMC1855592

17. Л.Г. Стоянова, Т.Д. Сультимова, С.Г. Ботина, А. И. Нетрусов, "Выделение и идентификация новых низинобразующих штаммов Lactococcus lactis subsp. Lactis из молока," Прикл. биохим. Микробиол., т. 42, но. 5, стр. 560 - 568, 2006. (L. G Stoyanova, T. D. Sul'timova, S. G. Botina, A. I. Netrusov, "The establishment of taxonomic state of new perspective bacteriocin-synthesis strains of Lactococci of different origin," Appl. Biochem. Microbiol., vol. 42, no. 5 , pp. $560-568,2006$.

18. L. G Stoyanova., N.S. Egorov, "Comparative description of new Lactococcus lactis ssp. lactis strains obtained by protoplast fusion methods," Microbiologiya, vol. 68, no. 2, pp. 235-240, 1999.

19. M. Z. Nuryshev, L. G. Stoyanova, F. I. Netrusov, "New Probiotic Culture of Lactococcus lactis ssp. Lactis: Effective Opportunities and Prospects," Journal of Microbial \& Biochemical Technology, vol. 8, no. 4, pp. 290-295, Jul. 2016.

DOI: $10.4172 / 1948-5948.1000299$ 